\title{
Characterization of Dissolved Organic Matter Removal during Biological Treatment of Commingled Chemical Industrial Wastewater: Relationship with Fluorescent Dissolved Organic Matter Transformation
}

\author{
Dong Wang, 2*, Can Wang ${ }^{3}$, Min Ji ${ }^{3}$, Li-ping Sun ${ }^{1,2}$, \\ Chunsheng Qiu ${ }^{1,2}$, Shang-lien $\mathrm{Lo}^{4}$ \\ ${ }^{1}$ School of Environmental and Municipal Engineering, Tianjin Chengjian University, Tianjin, P.R. China \\ ${ }^{2}$ Tianjin Key Laboratory of Aquatic Science and Technology, Tianjin, P.R. China \\ ${ }^{3}$ School of Environmental Science and Engineering, Tianjin University, Tianjin, P.R. China \\ ${ }^{4}$ Graduate Institute of Environmental Engineering, Taiwan University, Taipei, Taiwan
}

Received: 24 June 2018

Accepted: 25 November 2018

\begin{abstract}
In this study, the transformation characteristics of fluorescent dissolved organic matter (FDOM) were investigated to characterize the removal of dissolved organic matter (DOM) during biological treatment of commingled chemical industrial wastewater. The results of fluorescence excitation and emission spectroscopy and parallel factor analysis revealed three components $(\mathrm{C} 1, \mathrm{C} 2$, and $\mathrm{C} 3$ ) of FDOM, which were related not only to surface and sewage sources but also chemical industrial wastewater sources. Resin fractionation results showed that the removal of DOM was affected not only by substrate biodegradability but also by DOM generation, such as intermediates, end products, and soluble microbial products, during biological treatment. However, the same variation tendency between DOM and FDOM, based on molecular weight (MW) distribution, was observed during MW fractionation. The changes in DOM in $\mathrm{MW}>10 \mathrm{kDa}$ fraction apparently corresponded with $\mathrm{C} 2$ variation; the tendency of DOM removal in MW of $0.5-10 \mathrm{kDa}$ fraction was possibly related to the evolutions of all three components; and lastly, the removal of $\mathrm{DOM}$ in $\mathrm{MW}<0.5 \mathrm{kDa}$ fraction was found in accordance with $\mathrm{C} 1$ and $\mathrm{C} 3$ transformations. The removal and transformation of DOM and FDOM were investigated using gas chromatography-mass spectrometer and Fourier transform infrared spectroscopy.
\end{abstract}

Keywords: dissolved organic matter, fluorescent dissolved organic matter, fluorescence excitation and emission spectroscopy; industrial wastewater; parallel factor analysis

*e-mail: wangdong06@tcu.edu.cn 


\section{Introduction}

Commingled chemical industrial wastewater is a heterogeneous wastewater stream discharged from various factories in chemical industrial parks. This wastewater contains a complex mixture of dissolved organic matter (DOM). Various technologies and methods, such as advanced oxidation technologies and adsorption and biological treatments, have been applied to treat this industrial wastewater [1]. Biological treatment is an important wastewater management process [2]. However, DOM in the commingled chemical industrial wastewater exhibits refraction, toxicity, or inhibition characteristics, which adversely affect biological treatment processes [3]. Biological treatment processes also produce increased DOM, such as soluble microbial products (SMP), because of stress conditions during industrial wastewater treatment [4]. Therefore, effective removal of the DOM is essential to reduce the adverse effects on receiving waters, whereas the traditional monitoring parameters, such as chemical oxygen demand (COD) and 5-day biochemical oxygen demand $\left(\mathrm{BOD}_{5}\right)$, cannot provide information on the changes in DOM composition [5]dissolved organic matter (DOM. Detailed characterization of DOM should be revealed to understand the processes of DOM elimination during biological treatment.

A portion of compounds, such as phenols, polycyclic aromatic hydrocarbons (PAHs), and heterocyclic compounds, in commingled chemical industrial wastewater are typical fluorescent dissolved organic matters (FDOM) [6]. Meanwhile, proteins and humiclike substance of FDOM are considered to originate from surface and sewage sources in commingled chemical industrial wastewater. The generation of SMP during biological treatment is another source of FDOM [7]. These FDOM can be employed to distinguish the chemical composition of DOM and provide detailed information of DOM removal.

Advanced characterization techniques, such as gelpermeating chromatography, gas chromatography-mass spectrometry (GC-MS), Fourier transform infrared (FT-IR) spectroscopy, and fluorescence excitation and emission spectroscopy (EEM), have been conducted to obtain detailed information on FDOM transformation [8] EEM, comprising the fluorescence fingerprint of chromophoric structure, provides a simple and repeatable method for determining chemical information on organic matter in an aquatic sample [9]. Meanwhile, parallel factor analysis (PARAFAC) can identify individual components from overlapped fluorophore by mathematical model [10]. EEM coupled with PARAFAC has been used to identify the components of DOM in surface water, raw sewage, and effluent in recent years [7, 11]. Differential EEMs of influent and effluent samples coupled with fractionation and PARAFAC can provide additional information on FDOM transformation during biological treatment [12].
With increasing restrictions on the standard discharge limit in China, enhancement of biological treatment systems and the selection of advanced treatment processes were considered to efficiently treat chemical industrial wastewater. Hence, characteristics of DOM removal and components involving biological treatment effluent must be investigated. This study mainly aims to characterize DOM removal following FDOM transformation. Influents and effluents were sampled in a sequencing batch reactor (SBR) system by feeding an actual commingled chemical industrial wastewater. EEM-PARAFAC coupled with resin and molecular weight (MW) fractionation was used to investigate FDOM transformation.

\section{Materials and Methods}

\section{Wastewater Characteristics}

The raw industrial wastewater was collected from a full-scale wastewater treatment plant in Hangu Chemical Industrial Park, Tianjin, China. The wastewater contained more than 50 types of chemical industrial effluents, including pharmaceutical, manufacturing, petroleum chemical, electronic, chemical reagent, household, and personal care product industry effluents. The main physicochemical characterization of wastewater was as follows: COD, 982-1602 $\mathrm{mg} \cdot \mathrm{L}^{-1}$; $\mathrm{BOD}_{5}, \quad 208-824 \mathrm{mg} \cdot \mathrm{L}^{-1}$; total nitrogen (TN), 24.5-30.8 $\mathrm{mg} \cdot \mathrm{L}^{-1}$; ammonia nitrogen $\left(\mathrm{NH}_{4}^{+}-\mathrm{N}\right)$, 17.9-20.6 $\mathrm{mg} \cdot \mathrm{L}^{-1}$; total phosphorus (TP), 2.3-2.4 $\mathrm{mg} \cdot \mathrm{L}^{-1}$, $\mathrm{pH}, 7.2-8.5$; and total dissolved solids (TDS), 4.5-9.7 $\mathrm{g} \cdot \mathrm{L}^{-1}$. The discharge limit values (EPA of China) were shown in Table 1, and the effluent was finally discharged into a central wastewater treatment plant.

\section{Bench Scale Reactor and Operation}

An SBR system (2 L) was adopted to investigate the characteristics of DOM removal and FDOM transformation by feeding raw industrial wastewater. The system worked at room temperature and under the following conditions: $0.09 \mathrm{~h}$ of influent filling, $6 \mathrm{~h}$ of string, $14 \mathrm{~h}$ of aeration, $1.5 \mathrm{~h}$ of settling, $0.5 \mathrm{~h}$ of effluent withdrawal, and $1.91 \mathrm{~h}$ of idleness. Dissolved oxygen of the SBR system during the aeration stage was kept at $3.0 \mathrm{mg} \cdot \mathrm{L}^{-1}$.

The seeding sludge in SBR was collected and acclimated for 30 days. Sludge retention time and mixed liquor suspended solids were kept at 30 days and $4 \mathrm{~g} \cdot \mathrm{L}^{-1}$, respectively, in the SBR system.

\section{Sampling}

The influent and effluent of SBR were sampled and filtered through a $0.45-\mu \mathrm{m}$ glass fiber filter and were then stored at $4^{\circ} \mathrm{C}$ for further analysis. 
Table 1. Discharge limit values of effluent.

\begin{tabular}{|c|c|}
\hline Items & Discharge limit values \\
\hline $\mathrm{COD}$ & $500 \mathrm{mg} \cdot \mathrm{L}^{-1}$ \\
\hline $\mathrm{BOD}_{5}$ & $350 \mathrm{mg} \cdot \mathrm{L}^{-1}$ \\
\hline $\mathrm{NH}_{4}^{+}-\mathrm{N}$ & $45 \mathrm{mg} \cdot \mathrm{L}^{-1}$ \\
\hline $\mathrm{TN}$ & $70 \mathrm{mg} \cdot \mathrm{L}^{-1}$ \\
\hline $\mathrm{TP}$ & $8 \mathrm{mgVL}-1$ \\
\hline $\mathrm{pH}$ & $6.5-9.5$ \\
\hline
\end{tabular}

\section{Resin Fractionation}

DOM in influent and effluent samples in this study was fractionated into hydrophobic acid (HPO-A), hydrophobic neutral (HPO-N), transphilic acid (TPI-A), transphilic neutral (TPI-N), and hydrophilic (HPI) fractions. The procedure was in accordance with that in Bu's study [13], as shown in Appendix A1.

\section{MW Distribution}

The MW distribution of DOM was determined with a dead-end batch ultrafiltration apparatus. The procedure was in accordance with that introduced by Zhao et al. [14], as shown in Appendix A2. The samples filtered through a $0.45-\mu \mathrm{m}$ filter were pressed through the membrane disk with $120-\mathrm{kPa}$ pressure by an $\mathrm{N}_{2}$ tank. In the present study, the MW cutoffs of membrane disks used were $0.5,1,10$, and $100 \mathrm{kDa}$. The samples were collected in glass bottles and stored at $4^{\circ} \mathrm{C}$ for further analysis.

\section{GC-MS Analysis}

The compositions of the organic pollutants in the wastewater in various fractions were analyzed by GC-MS. The samples were extracted with $\mathrm{CH}_{2} \mathrm{Cl}_{2}$ according to the extraction procedure in Appendix A3.

\section{FT-IR Spectroscopy Analysis}

To investigate the organic pollutants in the various fractions, FT-IR analysis was applied. An aqueous sample was freeze-dried $\left(-75^{\circ} \mathrm{C}\right.$ and $3 \mathrm{kPa}$ pressure) and the dry powder sample (3 $\mathrm{mg}$ ) was thoroughly mixed with approximately $100 \mathrm{mg}$ of $\mathrm{KBr}$. The mixture was pressed into a pellet, and a Nicolet 6700 FT-IR spectrometer was used to record the infrared spectrum with a wavenumber range of 4000 to $400 \mathrm{~cm}^{-1}$. The absorbance bands at $3400 \mathrm{~cm}^{-1}$ were the absorbance of $\mathrm{H}_{2} \mathrm{O}$, which could not be avoided in $\mathrm{KBr}$ tablets.

\section{EEM Spectrum and PARAFAC}

EEM spectroscopy was conducted with a Fluorolog 3-21 spectrophotometer (Jobin Yvon Inc., USA) at room temperature. EEM spectra of the samples were obtained with emission wavelengths from 280 to $480 \mathrm{~nm}$ at 5 -nm increment and excitation wavelengths from 220 to $400 \mathrm{~nm}$ at 2-nm increments. The slit width was $5 \mathrm{~nm}$, and the scan rate was $2000 \mathrm{~nm} \cdot \mathrm{min}^{-1}$. To avoid innerfilter effects, all samples $(\mathrm{pH}=7)$ were diluted 50 -fold and the UV absorbance of the samples after 50-fold dilution was lower than $0.05 \mathrm{~cm}^{-1}$.

To investigate FDOM transformation, we obtained differential EEMs by subtracting the fluorescence intensities in the EEMs of influent and effluent samples (Equations 1 and 2). Negative data in the differential EEMs were replaced with zero.

$$
\begin{gathered}
\Delta \mathrm{EEMs}_{\text {influent-effluent }}=\mathrm{EEMs}_{\text {influent }}-\mathrm{EEMs}_{\text {effluent }} \\
\Delta \mathrm{EEMs}_{\text {effluent-influent }}=\mathrm{EEMs}_{\text {effluent }}-\mathrm{EEMs}_{\text {influent }}
\end{gathered}
$$

EEM spectrograms obtained by PARAFAC analysis were combined into the following 3D data array: 46 samples $\times 91$ excitations $\times 41$ emissions. Before analysis, EEMs of samples were subtracted by blank spectrum (Milli-Q water) to remove Raman scattering. To remove Rayleigh scattering, we replaced EEM data by zero at emission measurement at wavelength $\leq$ excitation wavelength $+10 \mathrm{~nm}$ and excitation wavelength starting from $300 \mathrm{~nm} \mathrm{[15].}$ In this work, PARAFAC was achieved using MATLAB 2008a and the N-way Toolbox (http://www.models. kvl.dk). The appropriate number of components was selected through core consistency diagnostics, as shown in Fig. A1 (supplementary material: Appendix A4).

The relative concentrations of the corresponding components in a given sample were estimated by the maximum fluorescence intensity $\left(F_{\max }\right)$ of each component in this sample. Fluorescence intensity can be calculated using Equation $3[15,16]$ :

$$
F_{n}=S_{n} \times E_{x(\max )} \times E_{m(\max )} \quad n=1, \ldots N
$$

...where $F_{n}$ is the fluorescence intensity of the $n^{\text {th }}$ component in the given sample; $S_{n}$ is the score of the $n^{\text {th }}$ component of the given sample generated from the PARAFAC model; and $E_{x(\max )}$ and $E_{m(\max )}$ are the maximum loadings of the excitation and emission spectra, respectively, for the $n^{\text {th }}$ component.

\section{Analytical Methods for Wastewater Quality}

Parameters $\mathrm{COD}, \mathrm{BOD}_{5}, \mathrm{pH}, \mathrm{TN}, \mathrm{NH}_{4}^{+}-\mathrm{N}, \mathrm{TP}$, and TDS were measured following standard method (Environment Protection Bureau of China). Dissolved organic carbon (DOC) was determined using a TOC analyzer (Shimadzu, Japan). The UV-Vis spectroscopy parameters of UV absorbance at $254 \mathrm{~nm}\left(\mathrm{UV}_{254}\right)$, specific UV absorbance at $254 \mathrm{~nm}\left(\mathrm{SUVA}_{254}\right)$, UV absorbance ratios at 250 and $365 \mathrm{~nm}\left(E_{2} / E_{3}\right)$, and UV absorbance ratios at 253 and $203 \mathrm{~nm}\left(E_{\mathrm{ET}} / E_{\mathrm{Bz}}\right)$ were 
Table 2. DOM variation in influent and SBR effluent samples.

\begin{tabular}{|c|c|c|c|c|c|}
\hline Samples & $\begin{array}{c}\text { COD } \\
\left(\mathrm{mg} \cdot \mathrm{L}^{-1}\right)\end{array}$ & $\begin{array}{c}\text { BOD } \\
\left(\mathrm{mg} \cdot \mathrm{L}^{-1}\right)\end{array}$ & $\begin{array}{c}\text { DOC } \\
\left(\mathrm{mg} \cdot \mathrm{L}^{-1}\right)\end{array}$ & $\begin{array}{c}\mathrm{UV}_{254} \\
\left(\mathrm{~cm}^{-1}\right)\end{array}$ & $\begin{array}{c}\mathrm{SUVA}_{254} \\
\left(\mathrm{~L}^{-1} \mathrm{mg}^{-1} \cdot \mathrm{cm}^{-1}\right)\end{array}$ \\
\hline Influent & $1092 \pm 210$ & $470 \pm 57$ & $351 \pm 75$ & $18.97 \pm 4.16$ & $0.05 \pm 0.001$ \\
\hline SBR effluent & $656 \pm 102$ & $30 \pm 3$ & $194 \pm 65$ & $10.57 \pm 3.13$ & $0.05 \pm 0.003$ \\
\hline
\end{tabular}

analyzed with a UV-Vis spectrophotometer (INESA, China).

\section{Results and Discussion}

\section{Organic Matter Variation during} Biological Treatment

Table 2 shows the removal performance of DOM during the biological treatment of commingled chemical industrial wastewater. Average removal efficiencies of $\mathrm{COD}(39 \%), \mathrm{BOD}_{5}(88 \%)$, and $\mathrm{DOC}(44 \%)$ were obtained. A similar tendency of $\mathrm{UV}_{254}$ change was observed in the influent and effluent samples, illustrating that biodegradable DOM was easily removed during treatment. Aromatic DOM was also selectively removed in accordance with the results of $\mathrm{UV}_{254}$. However, SUVA $_{254}$ was sustained during biological treatment. The result might be associated with selective elimination of DOM and aromatic organic matter.

\section{Componential Characterization by PARAFAC}

PARAFAC modeling of the samples showed that overlapping fluorophores were decomposed, and the corresponding components could be identified. The EEM spectra of FDOM in influent and effluent samples could be characterized by three different fractions (Figs 1 and 2) as follows: $\mathrm{Cl}$ (Peak T) found at $\mathrm{E}_{\mathrm{x}} / \mathrm{E}_{\mathrm{m}}=282 \mathrm{~nm} / 330 \mathrm{~nm} ; \mathrm{C} 2$ (Peak M) at $\mathrm{E}_{\mathrm{x}} / \mathrm{E}_{\mathrm{m}}=332 \mathrm{~nm} / 400 \mathrm{~nm}$; and $\mathrm{C} 3$ (Peak P), which presented two peaks at $\mathrm{E}_{\mathrm{x}} / \mathrm{E}_{\mathrm{m}}=294 \mathrm{~nm} / 345 \mathrm{~nm}$ and at $\mathrm{E}_{\mathrm{x}} / \mathrm{E}_{\mathrm{m}}=324 \mathrm{~nm} / 345 \mathrm{~nm}$.

Table 3 lists compounds related to the components $[9,15,17,18]$ dissolved organic matter (DOM. $\mathrm{C} 1$ is defined as soluble microbial by-product-like substances, tyrosine, and DNA in sewage source that originated upstream of biological treatment effluents of industrial wastewater; $\mathrm{Cl}$ could also represent aromatic hydrocarbons, particularly phenols, in chemical industrial wastewater source. C2 is related to microbial humic-like substances derived from upstream biological treatments, marine humic-like substances in natural surface water sources from seawater utilization, pipe network leakage, and pharmaceutical-like substances and hydrophobic acids in industrial wastewater sources. Meanwhile, C3 represented soluble microbial byproduct-like substances and tryptophan in natural surface water sources. This component also reflected the mixture of aromatic hydrocarbons, phenols, heterocyclic compounds, and PAHs in commingled chemical industrial wastewater. The EEM spectra and PARAFAC analysis showed that the organic compounds in commingled chemical industrial wastewater contained not only the microbially derived DOM from upstream biological treatment processes but also the chemical compounds discharged by individual factories.
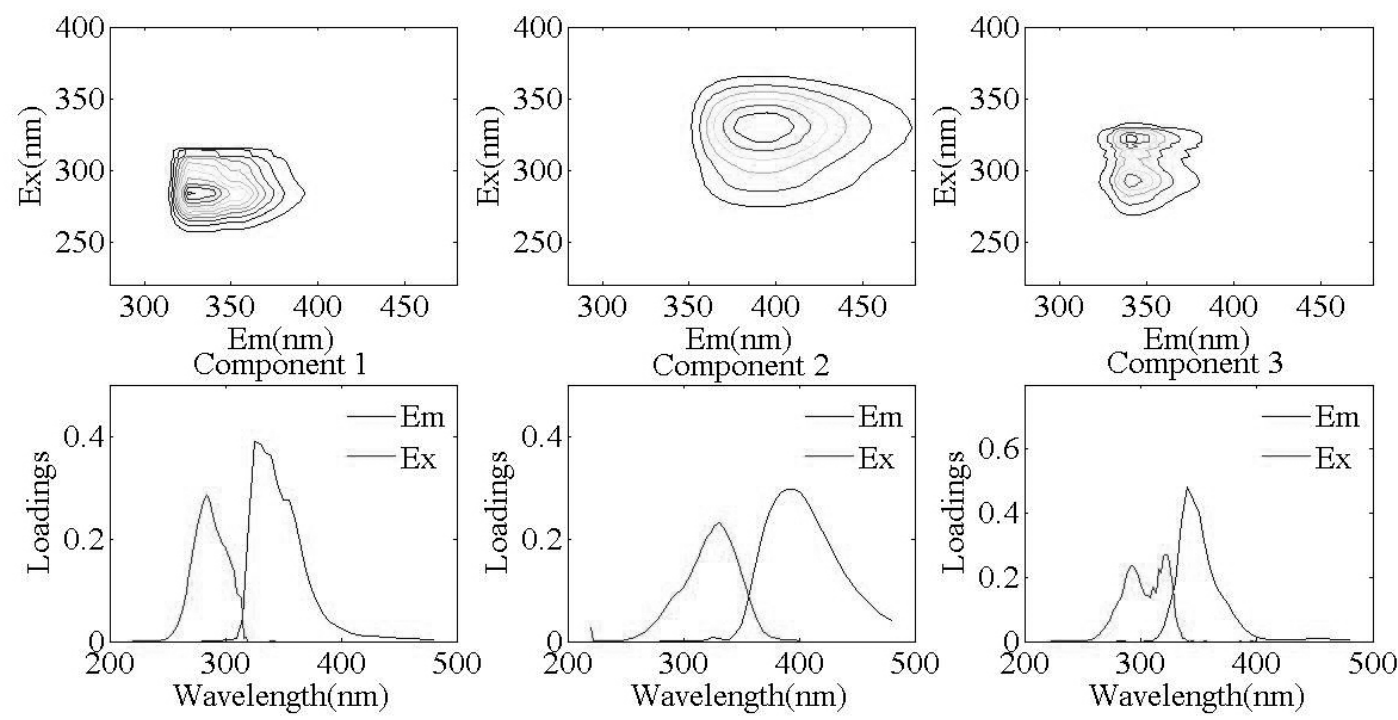

Fig. 1. Three components identified by PARAFAC and their loadings. 

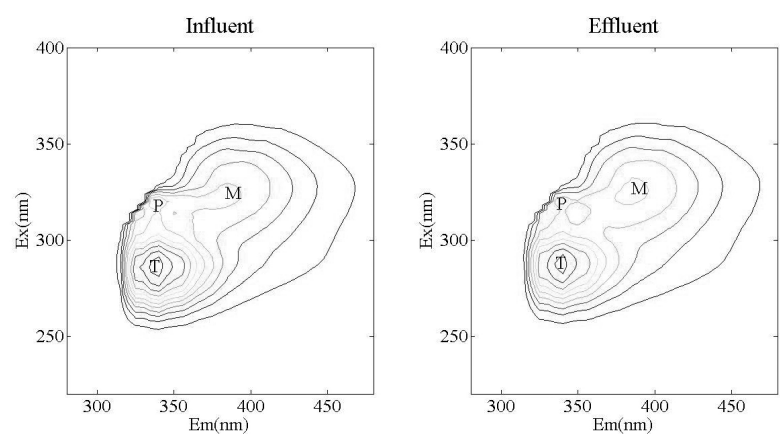

Fig. 2. EEM spectra of influent and effluent. The location and number of peaks (peaks T, P and M) were unchanged before and after biological treatment.

\section{Characteristics of FDOM Transformation before and after Treatment}

The variation in EEM spectra could reveal the characteristics of FDOM transformation before and after biological treatment. Comparison of the EEM spectra of influent and effluent samples showed that the location and number of peaks were unchanged (Fig. 2), but the shape and intensity of fluorescence peaks varied to a certain degree. The results showed that the components of FDOM could not be eliminated completely [19].

Table 4 shows fluorescence intensity $\left(F_{\max }\right)$ of the components in the influents and effluents by PARAFAC. The fluorescence intensity values of these components varied partially because of the poor biodegradability of FDOM [20]. The fluorescence intensity value of $\mathrm{C} 1$ decreased in the effluents, whereas the intensity values of $\mathrm{C} 2$ and $\mathrm{C} 3$ increased after treatment. These results indicated that $\mathrm{C} 1$ represented biodegradable characteristics, whereas $\mathrm{C} 2$ and $\mathrm{C} 3$ were refractory and
Table 4. Fluorescent intensity $\left(F_{\max }\right)$ of the components in the samples.

\begin{tabular}{|c|c|c|c|}
\hline \multirow{2}{*}{ Samples } & \multicolumn{3}{|c|}{$F_{\max }(\mathrm{AU})^{1}$} \\
\cline { 2 - 4 } & $\mathrm{C} 1$ & $\mathrm{C} 2$ & $\mathrm{C} 3$ \\
\hline Influent & $53.00 \pm 16.51$ & $32.00 \pm 10.52$ & $44.50 \pm 16.02$ \\
\hline SBR effluent & $36.50 \pm 12.52$ & $43.50 \pm 12.54$ & $63.50 \pm 23.57$ \\
\hline
\end{tabular}

contained microbial products. Previous research has shown that $\mathrm{C} 3$ in residual DOM of the effluent contained residual biodegradable and refractory components, intermediates, end products, and SMP [15, 21]. C2 increases were related to the generation of SMP under stressful conditions during biological treatment [4]. Finally, resin and MW fractionation should be applied to reveal much detail of DOM removal and FDOM transformation.

\section{Characteristics of DOM Removal and FDOM Transformation by Resin Fractionation and Differential EEM}

To confirm the characteristics of DOM removal and FDOM transformation during biological treatment, resin fractionation coupled with differential EEM was applied. The location and shape of EEMs in various polarity fractions varied significantly after biological treatment (Fig. A2). Peaks T (C1) and P (C3), related to soluble microbial by-product-like and protein-like sewage source and aromatic organic matter in industrial wastewater source, existed in all fractions; peak M (C2), originating from humic-like sewage source and hydrophobic acid industrial wastewater source, mainly

Table 3. Organic matter related to EEM peaks in previous studies.

\begin{tabular}{|c|c|c|c|c|c|c|}
\hline \multicolumn{3}{|c|}{ Current study } & \multicolumn{2}{|c|}{ Nature surface water and sewage sources } & \multicolumn{2}{|c|}{ Industrial wastewater source } \\
\hline Components & Peaks & $\begin{array}{c}\mathrm{Ex} / \mathrm{Em} \\
(\mathrm{nm} / \mathrm{nm})\end{array}$ & $\begin{array}{l}\text { Comparison } \\
\text { with other } \\
\text { studies }\end{array}$ & Description & $\begin{array}{l}\text { Comparison with other } \\
\text { studies }\end{array}$ & Description \\
\hline \multirow[b]{2}{*}{ Component 1} & \multirow[b]{2}{*}{ Peak T } & \multirow[b]{2}{*}{$282 / 330$} & \multirow{2}{*}{$\begin{array}{l}280 / 330[15] \\
275 / 304[17] \\
267 / 327[17]\end{array}$} & \multirow{2}{*}{$\begin{array}{c}\text { Soluble microbial by - } \\
\text { product-like; } \\
\text { Tyrosine } \\
\text { DNA }\end{array}$} & $266 / 300-400[15]$ & Toluene \\
\hline & & & & & $210-285 / 290-310[15]$ & Phenols \\
\hline \multirow[b]{2}{*}{ Component 2} & \multirow[b]{2}{*}{ Peak M } & \multirow[b]{2}{*}{$332 / 400$} & \multirow{2}{*}{$\begin{array}{l}325 / 385[17] \\
325 / 398[17]\end{array}$} & \multirow{2}{*}{$\begin{array}{l}\text { Marine humic-like; } \\
\text { Microbial humic }\end{array}$} & $308 / 410[18]$ & Carbamazepine \\
\hline & & & & & $340 / 425$ & $\begin{array}{c}\text { Related to } \\
\text { hydrophobic acids }\end{array}$ \\
\hline \multirow{6}{*}{ Component 3} & \multirow{4}{*}{ Peak T } & \multirow{4}{*}{$294 / 345$} & \multirow{4}{*}{$\begin{array}{l}280 / 330[15] \\
295 / 353[17]\end{array}$} & \multirow{4}{*}{$\begin{array}{c}\text { Soluble microbial by - } \\
\text { product-like; } \\
\text { Tryptophan }\end{array}$} & $220-335 / 310-410[9]$ & PAHs \\
\hline & & & & & $266 / 300-400[15]$ & Toluene \\
\hline & & & & & $210-285 / 290-310[15]$ & Phenols \\
\hline & & & & & $310-340 / 380-440[15]$ & Quinolone \\
\hline & \multirow{2}{*}{ Peak P } & \multirow{2}{*}{$324 / 345$} & & \multirow{2}{*}{ Undefined } & $220-335 / 310-410[9]$ & PAHs \\
\hline & & & & & $310-340 / 380-440[15]$ & Quinolone \\
\hline
\end{tabular}


appeared in HPO-N and TPI-A fractions in influent samples. After treatment, peaks $\mathrm{T}(\mathrm{C} 1)$ and $\mathrm{P}(\mathrm{C} 3)$ mainly existed in HPO and TPI fractions, whereas peak M (C2) mainly appeared in TPI-A and HPI fractions. From the differential EEMs, peaks T (C1) and $\mathrm{P}(\mathrm{C} 3)$ in acid fractions (HPO-A and TPI-A) and peak $\mathrm{T}(\mathrm{C} 1)$ in the TPI-N fraction were found to be partially removed during treatment. Peak T $(\mathrm{Cl})$ in the HPI fraction and peak M (C2) in the HPO-N fraction were almost completely eliminated. However, peak M (C2) in TPI-A and HPI fractions and peak P (C3) in neutral fraction (HPO-N and TPI-N) increased after biological treatment. The results showed that FDOM in various fractions were partially biodegradable, whereas several components of FDOM were generated during treatment. This finding explained why FDOM was removed with much difficulty during biological treatment, and FDOM fractionation could show additional details on FDOM removal and transformation characteristics.

Fig. 3 shows DOM removal (in terms of DOC) and FDOM transformation in various polarity fractions as obtained from $F_{\max }$ analysis. On the one hand, the DOM in HPO fractions was dominant and partially removed because of the adsorption or biodegradation of hydrophobic organic compounds by activated sludge [22]. On the other hand, FDOM in HPO fractions was insubstantial because of the low fluorescence characteristics of this organic matter in chemical industrial wastewater. DOM in TPI fractions accounted for $29 \%$ of total DOM, whereas FDOM in these fractions accounted for the major portion. In the TPI-A fraction, $\mathrm{C} 1$ and $\mathrm{C} 3$ could be partially removed, whereas $\mathrm{C} 2$ was generated during treatment. Hence, the refractory characteristics of DOM in TPI-A fraction were related to poor DOM biodegradability and generation of microbial products during treatment. In the TPI-N fraction, DOM was significantly removed, whereas FDOM represented refractory characteristics because non-FDOM was easily biodegraded in DOM. In the HPI fraction, DOM and $\mathrm{C} 1$ and $\mathrm{C} 3$ could be selectively biodegraded during treatment, whereas $\mathrm{C} 2$ in the HPI fraction increased because of microbial products.

FDOM did not represent the majority of DOM in the wastewater source sample, but FDOM transformation characteristics could reveal the details of DOM removal [7]. The value of $E_{2} / E_{3}$ could also be applied to estimate humification and MW [17]. The value of $E_{\mathrm{ET}} / E_{\mathrm{Bz}}$ could represent the ratio of the electrotransfer (ET) and benzenoid (Bz) band and reveal the
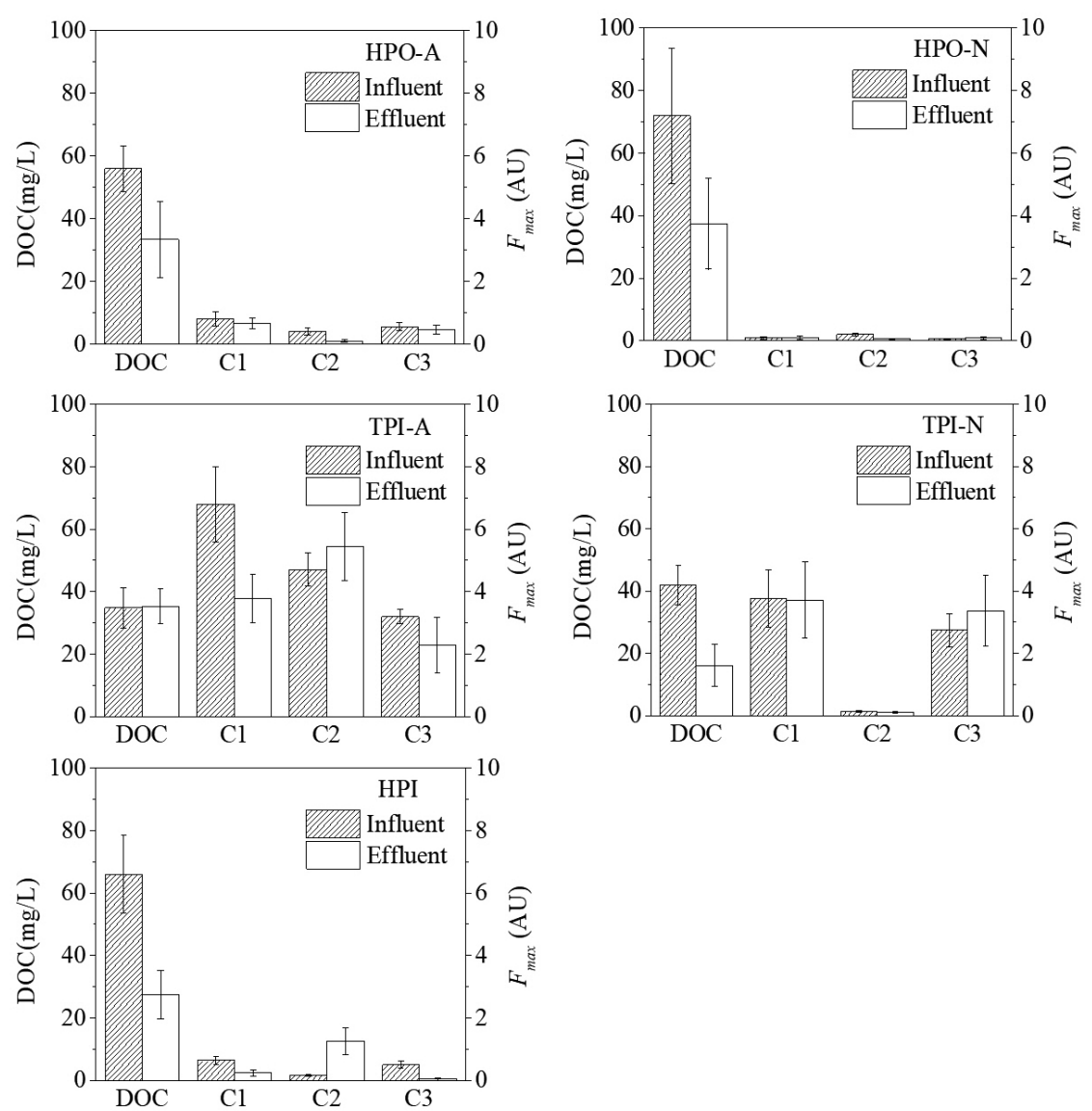

Fig. 3. Relationship of DOM removal and FDOM transformation in various polarity fractions. The DOM was represented by DOC values (the left axis), while the three components ( $\mathrm{C} 1, \mathrm{C} 2$ and $\mathrm{C} 3$ ) were showed by $F_{\max }$ values (the right axis). The results were repeated in three separate experiments and error bars represented the standard deviation from the mean. $F_{\max }$ values were calculated according to Equation 3. 
constitution and nature of DOM [23]. Table 5 shows the $E_{2} / E_{3}$ and $E_{\mathrm{ET}} / E_{\mathrm{Bz}}$ changes in DOM during treatment. $E_{2} / E_{3}$ in HPO-N and HPI fractions were considerably higher than those in other fractions, whereas $E_{2} / E_{3}$ in HPO-A and TPI-A fractions decreased. A low $E_{2} / E_{3}$ ratio was associated with a high degree of humification and large molecular size [24]. The ratio of $E_{\mathrm{ET}} / E_{\mathrm{Bz}}$ decreased significantly during treatment in HPO-A and TPI fractions and remained stable in HPO-N and HPI fractions. The increased $E_{\mathrm{ET}} / E_{\mathrm{Bz}}$ ratios suggested additional polar functional groups on the aromatic rings, whereas decreased ratios showed the absence of substitution on aromatic rings [25].

The above-mentioned results of FDOM transformation indicated that the $F_{\text {max }}$ decrease in $\mathrm{C} 2$ and increased humification in HPO-A fraction suggested that hydrophobic acids were removed from the HPO-A fraction. The decrease in $E_{\mathrm{ET}} / E_{\mathrm{Bz}}$ illustrated that the polar function groups decreased because the aromatic compounds were degraded by microorganisms. The DOM in HPO-N and HPI fractions showed extremely low humification and small molecular sizes. Thus, C2 decrease in HPO-N might be related to the removal of pharmaceutical-like substances by activated sludge, whereas C2 increase in the HPI fraction might be related to organic acid accumulation from substrate intermediates. The aromatic compounds with polar function groups showed refractory characteristics in HPO-N and HPI fractions. DOM in TPI-A fraction represented increased humification and molecular size because of humic-like substance (C2) accumulation from SMP. Hence, the removal of DOM in the TPI-A fraction during treatment is affected by humic-like substance accumulation. DOM in the TPI-N fraction showed decreased humification and molecular size, and the aromatic compounds with polar function groups were significantly removed during treatment.

\section{Characteristics of DOM Removal and FDOM Transformation in Various MW Fractions}

EEM coupled with MW fractionation revealed further details of FDOM removal and transformation (Fig. A3). In raw wastewater as influent, peaks $\mathrm{T}$ (C1) and $\mathrm{P}(\mathrm{C} 3)$, which are related to soluble microbial by-product-like and protein-like substances in sewage source and aromatic organic matter in industrial wastewater source, mainly existed in low MW fraction $(<10 \mathrm{kDa})$. Peak M (C2), which originated from humiclike substances in sewage source and hydrophobic acid industrial wastewater source, was found in $\mathrm{MW}>0.5$ $\mathrm{kDa}$. After treatment, peak M (C2) was partially removed from all fractions except in the 1-10 $\mathrm{kDa}$ fraction. From differential EEMs, FDOM in various MW fractions were found to be partially biodegraded except in the 1-10 kDa fraction. By contrast, peaks $\mathrm{T}$ (C1) and P (C3) were found in a wider MW range after treatment because of the appearance of $\mathrm{C} 1$ and $\mathrm{C} 3$ in the $10-100 \mathrm{kDa}$ fraction. An increase in all components

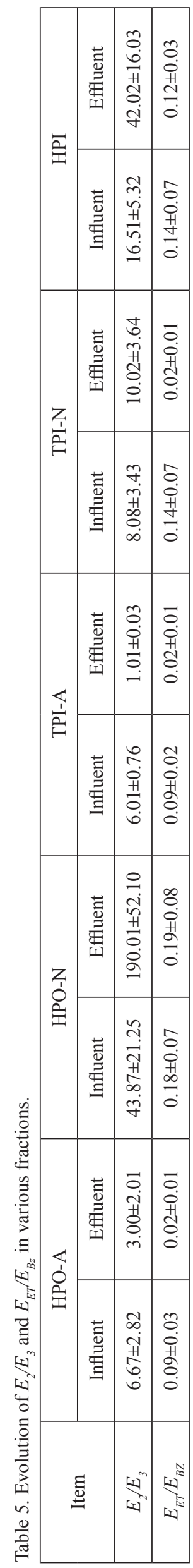


in the 1-10 $\mathrm{kDa}$ fraction was also observed after treatment.

As shown in Fig. 4, the bulk DOM and $\mathrm{C} 1$ and $\mathrm{C} 3$ of $\mathrm{FDOM}$ in the $\mathrm{MW}<0.5 \mathrm{kDa}$ fraction were dominated and selectively removed after treatment. In the $\mathrm{MW}>0.5 \mathrm{kDa}$ fraction, DOM and FDOM showed refractory characteristics and were slightly removed. DOM removal characteristics were also apparently related to FDOM transformation tendency. DOM removal in the $10 \mathrm{kDa} \mathrm{MW}-0.45 \mu \mathrm{m}$ fraction was affected by changes in $\mathrm{C} 2$ characteristics. DOM variation in the $0.5-10 \mathrm{kDa} \mathrm{MW}$ fraction was related to the transformation of the three components of FDOM. In particular, the increase in $\mathrm{DOM}$ in the $1-10 \mathrm{kDa}$ MW fraction was obtained after treatment because of SMP formation and the increase in three FDOM components. The removal of $\mathrm{DOM}$ in the $\mathrm{MW}<0.5 \mathrm{kDa}$ fraction exhibited the same tendency with $\mathrm{C} 1$ and $\mathrm{C} 3$ of FDOM. FDOM consisted of not only natural organic matter and SMP from nature surface water and sewage sources but also fluorescence organic matter from industrial wastewater source. $\mathrm{C} 1$ and $\mathrm{C} 3$, which showed small molecular sizes, affected the removal of DOM with small molecular size. On the contrary, C2, which represented a large molecular size, was related to the removal of DOM with large molecular size. However, Cuss and Guéguen [26] found similar results in that a protein-like substance was significantly correlated with the small-size group of DOM in nature water source, and a humic-like substance with the large-size group.

Identification of Organic Pollutants in Various Fractions by GC-MS and FT-IR

To reveal the details of DOM and FDOM removal and transformations, GC-MS and FT-IR analysis were utilized to identify the organic pollutants of the DOM and FDOM in various resin fractions. GC-MS with liquid-liquid extraction can identify the organic matter with $\mathrm{MW}<0.5 \mathrm{kDa}$ [27], while FT-IR was used to investigate residual organic matter in the various fractions.

The identification and removal performance of the organic pollutants in various resin fractions was determined by GC-MS and the results are shown in
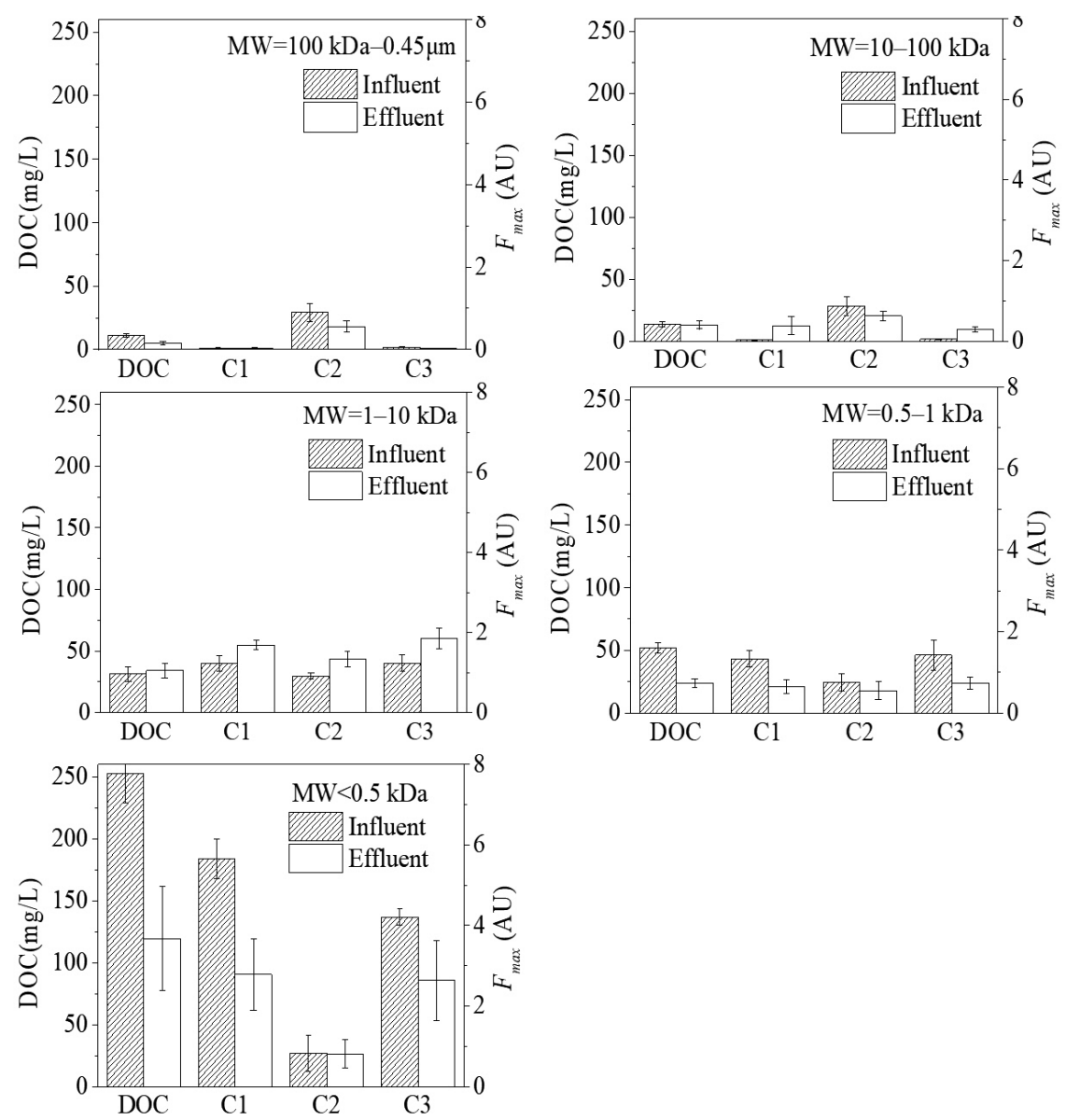

Fig. 4. Relationship of DOM removal and FDOM transformation in MW fractions. The DOM was represented by DOC values (the left axis), while the three components (C1, C2 and $\mathrm{C} 3$ ) were showed by $F_{\max }$ values (the right axis). The changes in DOM with large molecular size seemed to correspond with $\mathrm{C} 2$ variation, whereas the removal of DOM with low molecular weight was in accordance with $\mathrm{C} 1$ and $\mathrm{C} 3$ transformation. The results were repeated in three separate experiments and error bars represented the standard deviation from the mean. $F_{\max }$ values were calculated according to Equation 3. 
Table 6. While several of the pollutants cannot be identified by the database (National Institute of Standards and Technology), the unidentified pollutants accounted for a small fraction of the total peak area percentage. The organic pollutants discovered in the various fractions were mainly aromatic compounds that can be found in Table 6. In HPO-A fraction, 2, 4-dichloro-benzoic acid, a compound related to the pharmaceutical industry, dominated the DOM with low MW. Benzoic acids and phenols were also present in the TPI-A fraction, which were found in low concentrations. In HPO-N fraction, phthalates and PAHs were identified, as well as naphthalene, which was found in higher concentrations than the other compounds. In TPI-N fraction, quinoline and phenols were detected. A major pollutant of the TPI-N fraction was 2,4,6-tribromophenol, which was found in preservatives and fire retardant. However, the organic pollutants in HPI fraction cannot be efficiently extracted by liquidliquid extraction with $\mathrm{CH}_{2} \mathrm{Cl}_{2}$. Therefore, identities of the organic pollutants in HPI fraction were not obtained.

The organic matter with $\mathrm{MW}>0.5 \mathrm{kDa}$ was investigated by FT-IR analysis, as shown in Fig. 5. The peaks from the DOM in the TPI and HPI fractions were much more significant than those of the HPO fractions. These peaks indicate that the organic matter of $\mathrm{MW}>0.5 \mathrm{kDa}$ mainly existed in TPI and HPI fractions, while the organic matter of $\mathrm{MW}<0.5 \mathrm{kDa}$ dominated HPO fractions, which could be analyzed by GC-MS. In HPO-A fraction, the peaks at $1620-1450 \mathrm{~cm}^{-1}$ indicate the presence of the $\mathrm{C}=\mathrm{O}$ stretch of the carbonyl or simply the $\mathrm{C}=\mathrm{C}$ stretches of the aromatic ring, the compounds with $\mathrm{C}-\mathrm{O}$ stretches $\left(1240-1150 \mathrm{~cm}^{-1}\right)$ and polysaccharide-like materials with peaks of $1160-1120 \mathrm{~cm}^{-1}$ also existed in HPO-A fraction. In HPO-N fraction, the peaks at $1240-1150 \mathrm{~cm}^{-1}$ correspond to esters, alcohols and ethers, while peaks found in the range of $1620-1450 \mathrm{~cm}^{-1}$ suggest the presence of aromatic compounds. In TPI-A fraction, amide I $\left(1650 \mathrm{~cm}^{-1}\right)$ and amide II $\left(1540 \mathrm{~cm}^{-1}\right)$, indicated the presence of protein-like materials, which originated from upstream biological treatment processes or domestic sewage resources. C-O stretches with peaks of $1240-1150 \mathrm{~cm}^{-1}$ were also found in the TPI-A fraction. In TPI-N fraction, the DOM consisted of proteinlike substances $\left(1650 \mathrm{~cm}^{-1}\right.$ and $\left.1540 \mathrm{~cm}^{-1}\right)$, aromatic compounds (1620-1450 $\left.\mathrm{cm}^{-1}\right)$ and polysaccharide-like materials. Moreover, the peak at $2550 \mathrm{~cm}^{-1}$ also existed in the TPI-N fraction, which corresponds to SMP [28] treatment processes. In this work, SMP in activated sludge were characterized, fractionized, and quantified using integrated chemical analysis and mathematical approach. The utilization-associated products (UAP. In HPI fraction, fatty acid (1650-1550 $\mathrm{cm}^{-1}$ and $\left.1440-1350 \mathrm{~cm}^{-1}\right)$ and polysaccharide $\left(1160-1120 \mathrm{~cm}^{-1}\right)$ signals were found.

\section{Relationship of DOM Removal and FDOM Transformation in Various Fractions duringTreatment}

According to the results of pollutant identification before and after treatment (Table 6 and Fig. 5), the performance of the DOM removal in various resin

Table 6. Identification and removal performance of pollutants in various resin fractions by GC-MS.

\begin{tabular}{|c|c|c|c|}
\hline Fraction & Organic pollutant & $\begin{array}{l}\text { Relative percentage }{ }^{1} \\
\text { (Area \%) }\end{array}$ & $\begin{array}{c}\text { Relative removal efficiency }^{2} \\
(\%)\end{array}$ \\
\hline \multirow{2}{*}{ HPO-A } & 2, 4-dichloro-benzoic acid & $21.35-55.12$ & 37.56 \\
\hline & 3,5-di-tert-butyl-4-hydroxybenzal dehyde & $1.23-4.68$ & 49.84 \\
\hline \multirow{5}{*}{ HPO-N } & Dimethyl phthalate & $0.15-6.98$ & 91.23 \\
\hline & Dibutyl phthalate & $0.28-4.98$ & 42.20 \\
\hline & Naphthalene & $0.33-23.14$ & 80.03 \\
\hline & Methylnaphthalene & $0.28-6.06$ & 80.97 \\
\hline & Acenaphthene & $0.36-2.54$ & 10.6 \\
\hline \multirow{3}{*}{ TPI-A } & Benzenecarboxylic acid & $0.44-1.64$ & 87.23 \\
\hline & 2-methyl-benzoic acid & $0.47-1.76$ & 78.25 \\
\hline & 4-tert-butyl-2,6-disopropyphenol & $0.66-5.53$ & 14.38 \\
\hline \multirow{3}{*}{ TPI-N } & Quinoline & $0.27-2.93$ & 64.00 \\
\hline & 2,4,6-tribromophenol & $0.10-27.22$ & 60.04 \\
\hline & 2,4-di-tert-butyl-phenol & $0.75-3.99$ & 14.38 \\
\hline
\end{tabular}

${ }^{1}$ - Relative percentage was achieved according to the peak area percentage of total. The total peak area was obtained by GC-MS results of raw wastewater. Interval values of relative percentage were provided by GC-MS results over two years.

${ }^{2}$ - Relative removal efficiency was calculated by the peak area of GC-MS results both before and after treatment. 

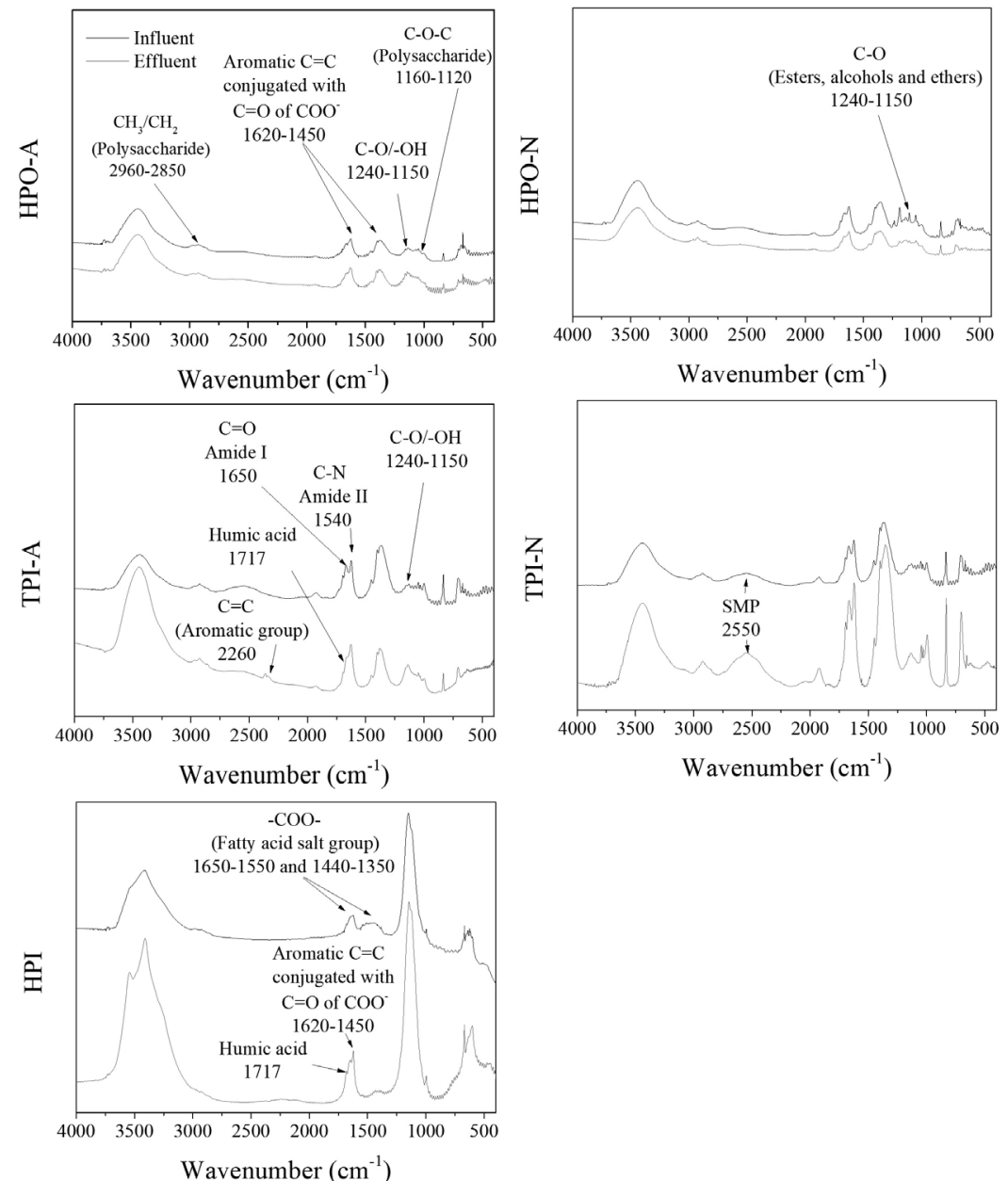

Fig. 5. FT-IR spectra of organic pollutants before and after treatment in various resin fractions.

fractions was mainly dependent on the removal of low molecular weight DOM. The representative organic pollutants, such as 2, 4-dichloro-benzoic acid in HPO-A fraction, naphthalene in HPO-N fraction and 2,4,6-tribromophenol in TPI-N fraction, may impact polarity and removal performance of wastewater. DOM with high $\mathrm{MW}(\mathrm{MW}>0.5 \mathrm{kDa})$ showed refractory characteristics, and some of the organic matter corresponded to microbial products. Hence, some of the components were found to increase during treatment. In HPO fractions, removal of low molecular weight DOM mainly contributed to DOM removal performance, while DOM with high MW (MW $>0.5 \mathrm{kDa})$ showed refractory characteristics except for the esters, alcohols and ethers present in HPO-N fraction. In TPI-A fraction, protein-like substances and aromatic compounds were partially removed, corresponding to $\mathrm{C} 1$ and $\mathrm{C} 3$ removal, respectively (Fig. 3). Both the FT-IR and EEM-PARAFAC results showed there was an increase in humic-like substances related to SMP generation. The compounds with $\mathrm{C}-\mathrm{O}$ stretches were also generated in TPI-A fraction, which belonged to intermediates and end products of pollutants during treatment. In TPI-N fraction, protein-like substances (C3) and polysaccharides increased due to SMP generation.
The increase of a peak at $2550 \mathrm{~cm}^{-1}$ was also related to biomass-associated products of SMP [28]. In HPI fraction, fatty acids were removed during biological treatment, while aromatic compounds, humic-like substance (C2) and polysaccharides were generated. Humic-like substance and polysaccharide also originated from SMP generation.

In general, the results above demonstrate that FDOM could be utilized to reveal detailed information of DOM removal and the components of the residual organic matter during treatment. FDOM in this commingled industrial wastewater originated not only from industrial wastewater sources but also from natural and sewage sources. $\mathrm{C} 1$ and $\mathrm{C} 3$ coincide with the small $\mathrm{MW}$ group of DOM, which mainly belonged to industrial wastewater and sewage sources, while $\mathrm{C} 2$ corresponds to the large MW group of DOM, which may be related to natural and sewage sources.

\section{Conclusions}

Given the results, DOM removal characteristics could be revealed by FDOM transformation by EEMPARAFAC and fractionation. The three components 
Units and Nomenclature

\begin{tabular}{|c|c|c|}
\hline Abbreviation & Items and nomenclature & Unit \\
\hline $\mathrm{BOD}_{5}$ & $\begin{array}{l}\text { 5-day biochemical oxygen } \\
\text { demand }\end{array}$ & $\mathrm{mg} \cdot \mathrm{L}^{-1}$ \\
\hline COD & Chemical oxygen demand & $\mathrm{mg} \cdot \mathrm{L}^{-1}$ \\
\hline DOC & Dissolved organic carbon & $\mathrm{mg} \cdot \mathrm{L}^{-1}$ \\
\hline DOM & Dissolved organic matter & - \\
\hline$E_{2} / E_{3}$ & $\begin{array}{l}\text { UV absorbance ratios at } 250 \text { and } \\
365 \mathrm{~nm}\end{array}$ & - \\
\hline EEM & $\begin{array}{c}\text { Fluorescence excitation and emis- } \\
\text { sion spectroscopy }\end{array}$ & - \\
\hline$E_{\mathrm{ET}} / E_{\mathrm{Bz}}$ & $\begin{array}{l}\text { UV absorbance ratios at } 253 \text { and } \\
203 \mathrm{~nm}\end{array}$ & - \\
\hline FDOM & $\begin{array}{l}\text { Fluorescent dissolved organic } \\
\text { matter }\end{array}$ & - \\
\hline$F_{\max }$ & Maximum fluorescence intensity & $\mathrm{AU}$ \\
\hline FT-IR & $\begin{array}{l}\text { Fourier Transform Infrared } \\
\text { Spectroscopy }\end{array}$ & \\
\hline GC-MS & $\begin{array}{l}\text { Gas Chromatography-Mass } \\
\text { Spectrometer }\end{array}$ & \\
\hline HPI & Hydrophilic fraction & - \\
\hline HPO-A & Hydrophobic acid fraction & - \\
\hline HPO-N & Hydrophobic neutral fraction & - \\
\hline MW & Molecular weight & - \\
\hline $\mathrm{NH}_{4}^{+}-\mathrm{N}$ & Ammonia nitrogen & $\mathrm{mg} \cdot \mathrm{L}^{-1}$ \\
\hline PAHs & Polycyclic aromatic hydrocarbons & - \\
\hline PARAFAC & Parallel factor analysis & - \\
\hline SBR & Sequencing batch reactor & - \\
\hline SMP & Soluble microbial products & - \\
\hline SUVA $_{254}$ & Specific UV absorbance at $254 \mathrm{~nm}$ & L.mg-1 $\mathrm{cm}^{-1}$ \\
\hline TDS & Total dissolved solids & $g \cdot L^{-1}$ \\
\hline $\mathrm{TN}$ & Total nitrogen & $\mathrm{mg} \cdot \mathrm{L}^{-1}$ \\
\hline $\mathrm{TP}$ & Total phosphorus & $\mathrm{mg} \cdot \mathrm{L}^{-1}$ \\
\hline TPI-A & Transphilic acid fraction & - \\
\hline TPI-N & Transphilic neutral fraction & - \\
\hline $\mathrm{UV}_{254}$ & UV absorbance at $254 \mathrm{~nm}$ & $\mathrm{~cm}^{-1}$ \\
\hline
\end{tabular}

related to sewage source and industrial wastewater source were identified by PARAFAC analysis. DOM removal characteristics in various polarity fractions were affected by not only substrate biodegradability but also DOM generation. However, in MW fractions, the DOM removal characteristics were related to the FDOM transformation. The changes in DOM with large molecular size corresponded with $\mathrm{C} 2$ variation, whereas the removal of DOM with low MW was in accordance with $\mathrm{C} 1$ and $\mathrm{C} 3$ transformation. The organic pollutants in various fractions were identified by GC-MS and FT-IR analysis. The results demonstrated that FDOM could be utilized to reveal the intricate details of DOM removal and to identify the components of the residual organic matter found during treatment.

\section{Acknowledgements}

The authors wish to thank the Natural Science of Foundation of China (51608350 and 51478291) and the Mega-Projects of Science Research for Water Environment improvement (2015ZX07203) for the partial support of this study.

\section{Conflict of Interest}

The authors declare no conflict of interest.

\section{References}

1. KAHOUSH M., BEHARY N., CAYLA A., NIERSTRASZ V. Bio-Fenton and Bio-electro-Fenton as sustainable methods for degrading organic pollutants in wastewater. Process Biochem., 64, 237, 2018.

2. PRADHAN D., SUKLA L.B., SAWYER M., RAHMAN P.K.S.M. Recent bioreduction of hexavalent chromium in wastewater treatment: A review. J. Ind. Eng. Chem., 55, 1, 2017.

3. KIM Y.M., PARK, D., LEE D.S., PARK J.M. Inhibitory effects of toxic compounds on nitrification process for cokes wastewater treatment. J. Hazard. Mater., 152 (3), $915,2008$.

4. WANG Z.P., ZHANG T. Characterization of soluble microbial products (SMP) under stressful conditions. Water Res., 44 (18), 5499, 2010.

5. CUI Y., WU Q., YANG M., CUI F. Three-dimensional excitation-emission matrix fluorescence spectroscopy and fractions of dissolved organic matter change in landfill leachate by biological treatment. Environ. Sci. Pollut. Res., 23, 1, 2016.

6. ZHANG W., WEI C., YAN B., FENG C., ZHAO G., LIN C., YUAN M., WU C., REN Y., HU Y. Identification and removal of polycyclic aromatic hydrocarbons in wastewater treatment processes from coke production plants. Environ. Sci. Pollut. Res., 20, 6418, 2013.

7. YU H., QU F., SUN L., LIANG H., HAN Z., CHANG H., SHAO S., LIN G. Relationship between soluble microbial products (SMP) and effluent organic matter (EfOM): Characterized by fluorescence excitation emission matrix coupled with parallel factor analysis. Chemosphere, 121 (4), 101, 2015.

8. MICHAEL-KORDATOU I., MICHAEL C., DUAN X., HE X., DIONYSIOU D.D., MILLS M.A., FATTA-KASSINOS D. Dissolved effluent organic matter: Characteristics and potential implications in wastewater treatment and reuse applications. Water Res., 77, 213, 2015.

9. FERRETTO N., TEDETTI M., GUIGUE C., MOUNIER S., REDON R., GOUTX M. Identification and quantification of known polycyclic aromatic hydrocarbons and pesticides in complex mixtures using fluorescence excitation-emission matrices and parallel factor analysis. Chemosphere, 107, 344, 2014.

10. WU J., ZHANG H., HE P.J., SHAO L.M. Insight into the heavy metal binding potential of dissolved organic matter in MSW leachate using EEM quenching combined with PARAFAC analysis. Water Res., 45, 1711, 2011.

11. CARSTEA E.M., BRIDGEMAN J., BAKER A., REYNOLDS D.M. Fluorescence spectroscopy for 
wastewater monitoring: A review. Water Res., 95, 205, 2016.

12. HE W., HUR J. Conservative behavior of fluorescence EEM-PARAFAC components in resin fractionation processes and its applicability for characterizing dissolved organic matter. Water Res., 83, 217, 2015.

13. BU L., WANG K., ZHAO Q.L., WEI L.L., ZHANG J., YANG J.C. Characterization of dissolved organic matter during landfill leachate treatment by sequencing batch reactor, aeration corrosive cell-Fenton, and granular activated carbon in series. J. Hazard. Mater., 179 (1-3), 1096, 2010.

14. ZHAO R., NOVAK J.T., GOLDSMITH C.D. Evaluation of on-site biological treatment for landfill leachates and its impact: A size distribution study. Water Res., 46 (12), 3837, 2012.

15. OU H.S., WEI C.H., MO C.H., WU H.Z., REN Y., FENG C.H. Novel insights into anoxic/aerobic ${ }^{1} /$ aerobic $^{2}$ biological fluidized-bed system for coke wastewater treatment by fluorescence excitation-emission matrix spectra coupled with parallel factor analysis. Chemosphere, 113, 158, 2014.

16. KOWALCZUK P., DURAKO M.J., YOUNG H., KAHN A.E., COOPER W.J., GONSIOR M. Characterization of dissolved organic matter fluorescence in the South Atlantic Bight with use of PARAFAC model: Interannual variability. Mar. Chem., 113 (3-4), 182, 2009.

17. WANG L., WU F., ZHANG R., LI W., LIAO H. Characterization of dissolved organic matter fractions from Lake Hongfeng, Southwestern China Plateau. J. Environ. Sci., 21, 581, 2009.

18. CHEN W., WESTERHOFF P., LEENHEER J.A., BOOKSH K. Fluorescence Excitation-Emission Matrix Regional Integration to Quantify Spectra for Dissolved Organic Matter. Environ. Sci. Technol., 37 (24), 5701, 2003.

19. MURPHY K.R., HAMBLY A., SINGH S., HENDERSON R.K., BAKER A., STUETZ R., KHAN S.J. Organic matter fluorescence in municipal water recycling schemes:
Toward a unified PARAFAC model. Environ. Sci. Technol., 45 (7), 2909, 2011.

20. YANG X., ZHOU Z., RAJU M.N., CAI X., MENG F. Selective elimination of chromophoric and fluorescent dissolved organic matter in a full-scale municipal wastewater treatment plant. J. Environ. Sci., 57, 150, 2017.

21. BARKER D.J., STUCKEY D.C. A review of Soluble Microbial Products (SMP) in Wastewater Treatment Systems. Water Res., 33 (14), 3063, 1999.

22. CHEN C., ZHANG X., ZHU L., HE W., HAN H. Changes in different organic matter fractions during conventional treatment and advanced treatment. J. Environ. Sci., 23 (4), 582, 2011.

23. HE X.S., XI B.D., JIANG Y.H., HE L.S., LI D., PAN H.W., BAI S.G. Structural transformation study of water-extractable organic matter during the industrial composting of cattle manure. Microchem. J., 106, 160, 2013.

24. HE W., LEE J.H., HUR J. Anthropogenic signature of sediment organic matter probed by UV-Visible and fluorescence spectroscopy and the association with heavy metal enrichment. Chemosphere, 150, 184, 2016.

25. FUENTES M., GONZÁLEZ-GAITANO G., GARCIAMINA J. The Usefulness of UV-Visible and Fluorescence Spectroscopies to Study the Chemical Nature of Humic Substances from Soils and Composts. Org. Geochem., 37, 1949, 2006.

26. CUSS C.W., GUÉGUEN C. Relationships between molecular weight and fluorescence properties for sizefractionated dissolved organic matter from fresh and aged sources. Water Res., 68, 487, 2015.

27. KUNACHEVA C., LE C., SOH Y.N.A., STUCKEY D.C. Chemical Characterization of Low Molecular Weight Soluble Microbial Products in an Anaerobic Membrane Bioreactor. Environ. Sci. Technol., 51(4), 2254, 2017.

28. NI B.J., ZENG R.J., FANG F., XIE W.M., SHENG G.P., YU H.Q. Fractionating soluble microbial products in the activated sludge process. Water Res., 44 (7), 2292, 2010. 


\section{Appendix A. Supplementary material}

\section{A1. Supplemental Methods for Resin Fractionation}

Organic matters in influent and effluent samples in this study were divided based on polarity into hydrophobic fractions (HPO-A and HPO-N), transphilic fractions [transphilic acid (TPI-A) and transphilic neutral (TPI-N)], and hydrophilic fraction (HPI). Fractionation was conducted as follows: $0.5 \mathrm{~L}$ of sample was fractionated by two serial columns filled with Amberlite XAD-8 and XAD-4 resins. The resins were cleaned with methanol and acetonitrile by Soxhlet extraction method for $12 \mathrm{~h}$ before addition into the columns. The samples from influent and effluent of the SBR system were first filtered through a $0.45 \mu \mathrm{m}$ glass fiber filter to remove suspended solids. The filtrate was then acidified to a $\mathrm{pH}$ of 2 with $6 \mathrm{M} \mathrm{HCl}$ and passed through the XAD-8 and XAD-4 resin columns in series. Materials retained on XAD-8 were hydrophobic fractions, whereas materials retained on XAD-4 were transphilic fractions. The materials not retained on either resin comprised the HPI fraction. HPO-A and TPI-A were eluted by backwashing with $0.1 \mathrm{M}$ $\mathrm{NaOH}$ from the XAD-8 and XAD-4 columns, respectively. The resins were washed with distilled water and extracted with a solution of $75 \%$ acetonitrile and $25 \%$ ultrapure water (Millipore Milli-Q). Extracts from the XAD-8 and XAD-4 columns were condensed by rotary evaporator and then freeze-dried. Next, the extracts were separately redissolved in Milli-Q water with $\mathrm{pH}$ 7, which comprised the HPO-N for XAD-8 columns and TPI-N for XAD-4 columns.

\section{A2. Supplemental Methods for MW Distribution}

The apparent molecular weight (MW) distribution of organic matter was characterized by a dead-end batch ultrafiltration apparatus. The experimental procedure was conducted as follows: Wastewater samples were first filtered through a $0.45 \mu \mathrm{m}$ filter to remove suspended solids. Then, about $240 \mathrm{ml}$ of wastewater sample was pressed through the membrane disc $(63.5 \mathrm{~mm})$ driven by pressure $(120 \mathrm{kPa})$ from an $\mathrm{N}_{2}$ tank. The $\mathrm{MW}$ cut-offs of membrane discs used in the present study were $0.5 \mathrm{k}, 1 \mathrm{k}, 10 \mathrm{k}$, and $100 \mathrm{k}$ Da. Wastewater samples were collected in glass bottles and stored at $4^{\circ} \mathrm{C}$ for further analysis.

\section{A3. GC-MS Analysis}

Aqueous samples were filtered with $0.45 \mu \mathrm{m}$ glass filters and stored at $4^{\circ} \mathrm{C}$. Based on the contents of organic compounds, $200 \mathrm{ml}$ of raw wastewater and treated effluents were extracted with $\mathrm{CH}_{2} \mathrm{Cl}_{2}$ under acidic, neutral, and alkaline conditions. The compositions of organic compounds in the wastewater were analyzed via GC-MS. Then $1 \mu \mathrm{L}$ pretreated extracted samples were injected into the GC-MS system (Agilent, USA). The carrier gas was pure helium at a flow rate of $1 \mathrm{ml} \cdot \mathrm{min}^{-1}$. A $30 \mathrm{~m}$-long HP-5MS capillary column with an inner diameter of $0.25 \mathrm{~mm}$ was used in the separation system. The temperature control program was implemented as follows. The initial temperature of $40^{\circ} \mathrm{C}$ was maintained for $4 \mathrm{~min}$. Afterward, the oven temperature was increased to $250^{\circ} \mathrm{C}$ at a rate of $5^{\circ} \mathrm{C} \cdot \mathrm{min}^{-1}$, to $300^{\circ} \mathrm{C}$ at a rate of $10^{\circ} \mathrm{C} \cdot \mathrm{min}^{-1}$, and then maintained for $10 \mathrm{~min}$. Organic compound analysis was conducted according to the National Institute of Standards and Technology 05 mass spectral library database.

\section{A4. Results of Core Consistency Diagnostic with Different Numbers of Components}

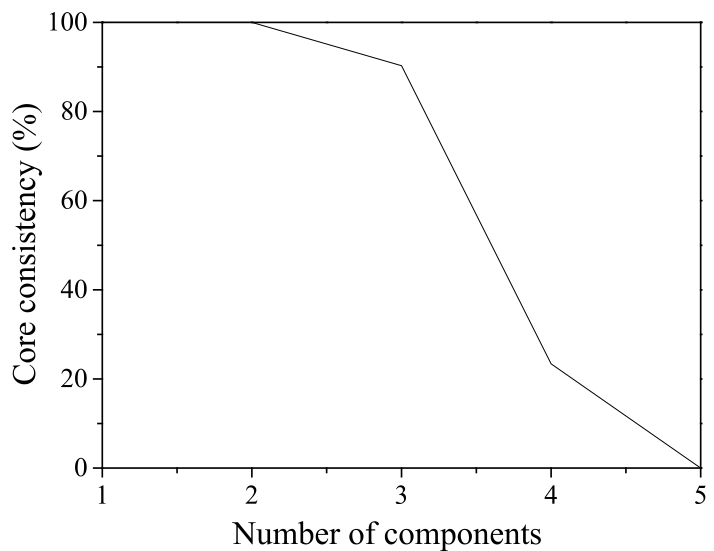

Fig. A1. Core consistency diagnostic with different numbers of components; the largest decrease in core consistency occurred when adding a fourth component. 


\section{A5. EEM and Differential EEM Spectra of FDOM in Various Polarity Fractions of Influent and Effluent Samples}
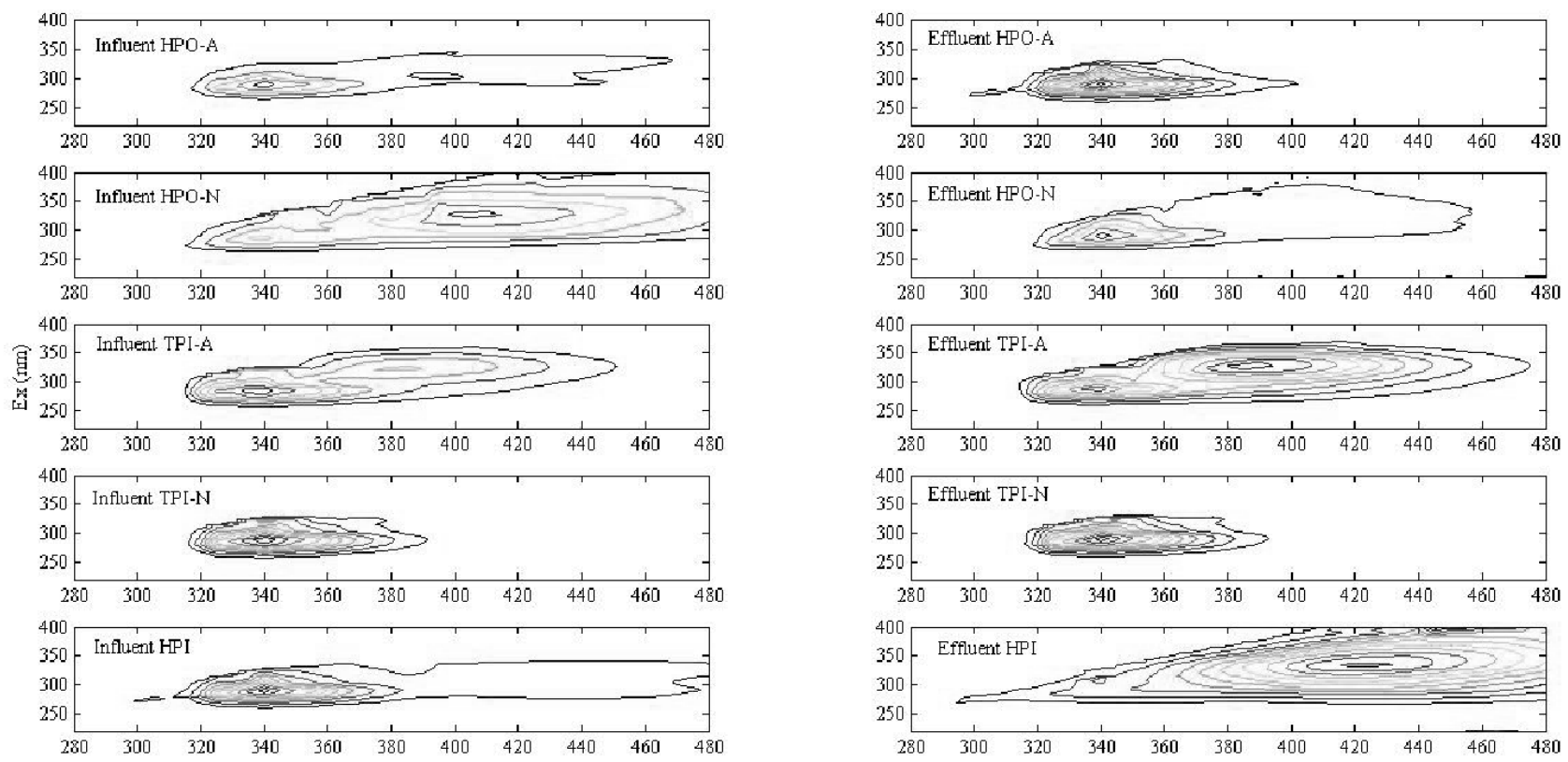

$\operatorname{Em}(\mathbf{n m})$
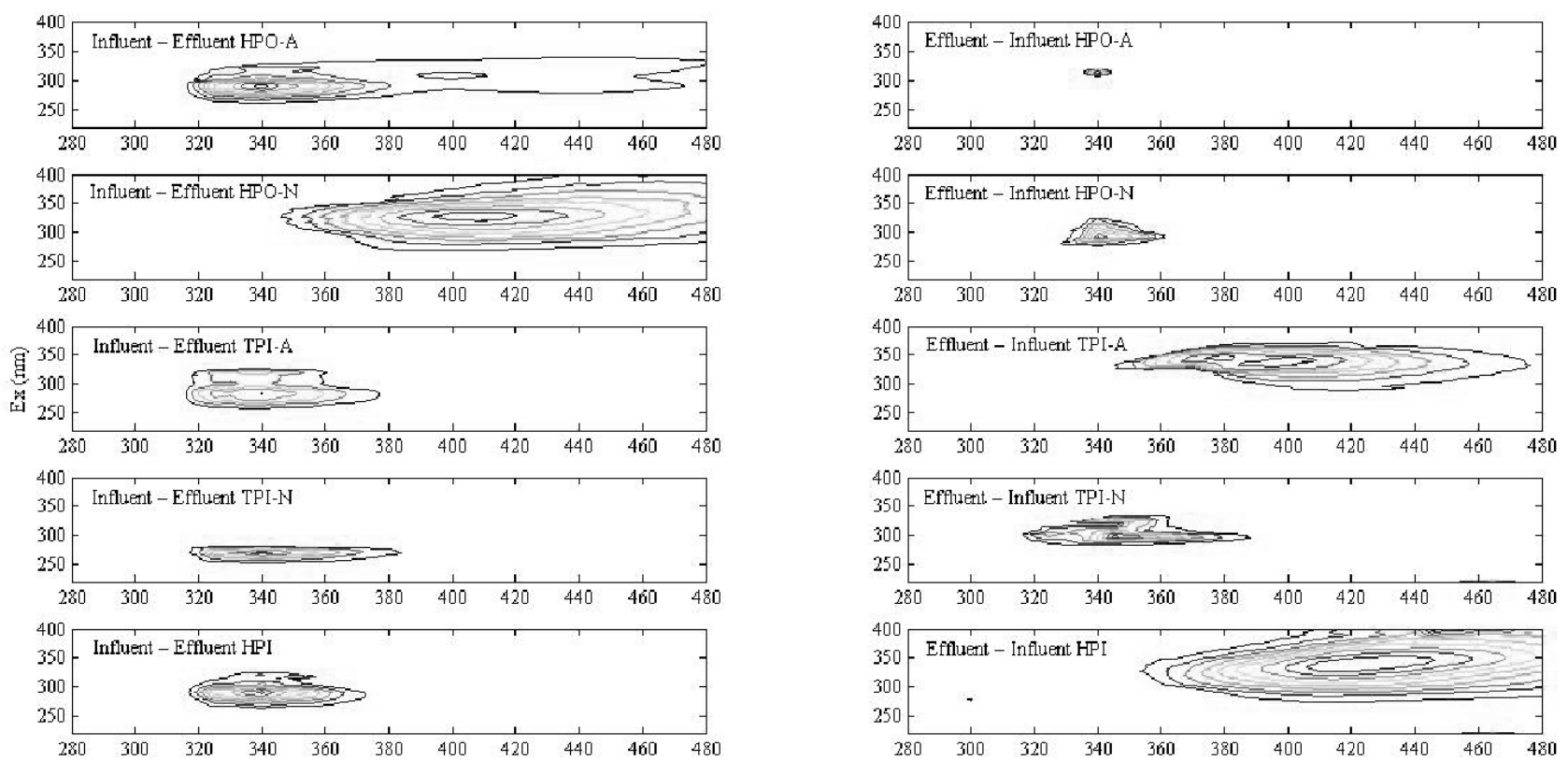

$\operatorname{Em}(\mathrm{nm})$

Fig. A2. EEM and differential EEM spectra of FDOM in various polarity fractions of influent and effluent samples; the removed and generated FDOM was observed by differential EEMs. The differential EEMs (influent-effluent) were calculated according to Equation 1. The differential EEMs (effluent-influent) were calculated according to Equation 2. 


\section{A6. EEM and Differential EEM Spectra of FDOM in MW Fractions of Influent and Effluent Samples}
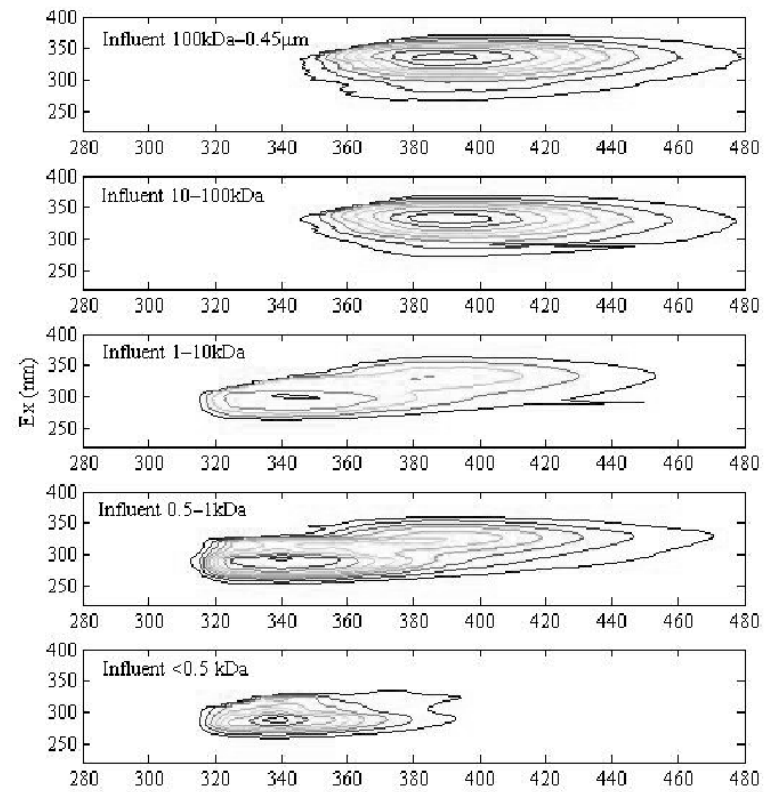

$\operatorname{Em}(\mathrm{nm})$
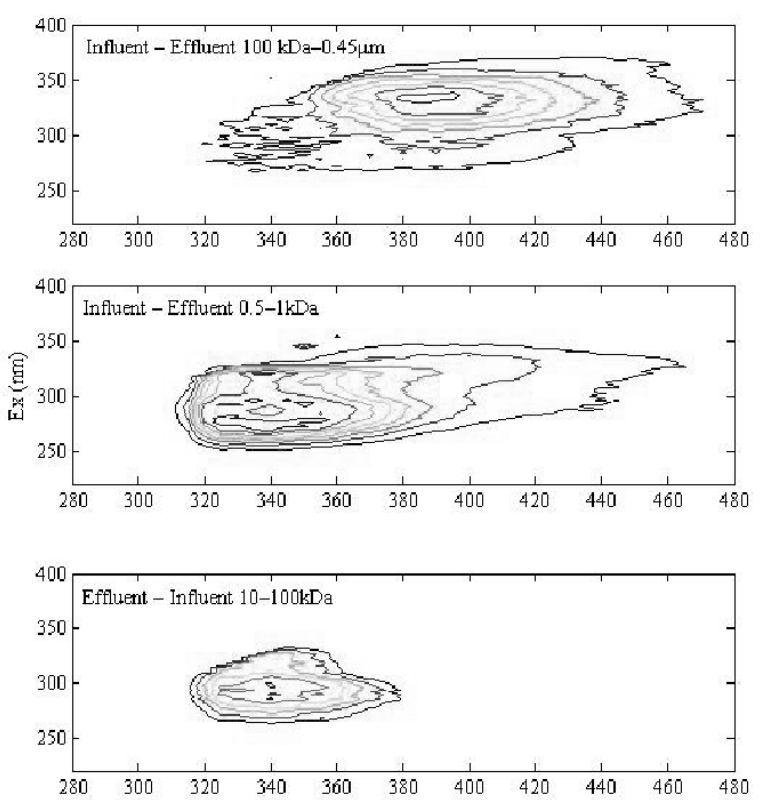
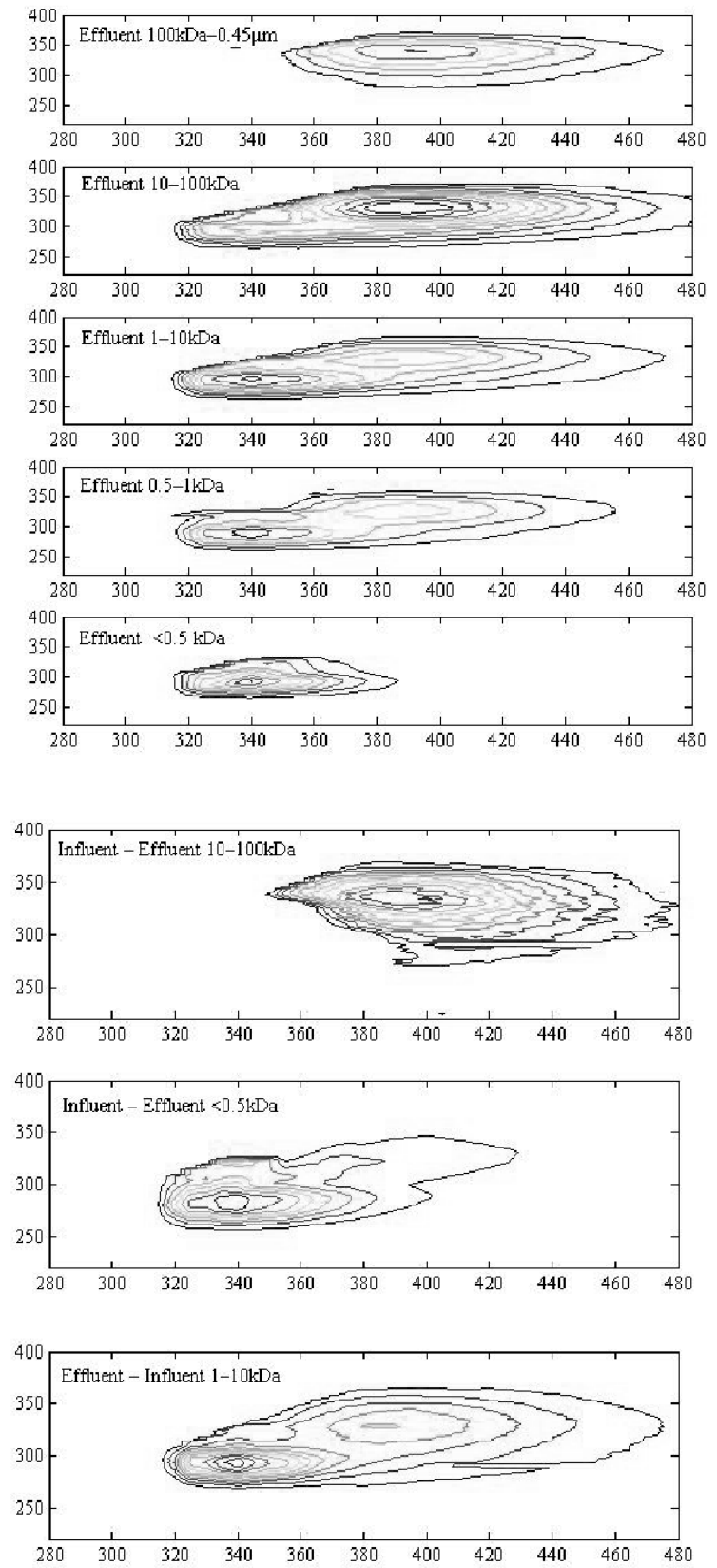

$\mathrm{Em}(\mathrm{nm})$

Fig. A3. EEM and differential EEM spectra of FDOM in MW fractions of influent and effluent samples; the removed and generated FDOM during biological treatment was revealed by differential EEMs. The differential EEMs (influent-effluent) were calculated according to Equation 1, and the differential EEMs (influent-effluent) were calculated according to Equation 2. 


\section{A7. List of Band Assignment for FT-IR Spectra}

Table A1. List of band assignment for FT-IR spectra [13].

\begin{tabular}{|c|c|}
\hline Wave number $\left(\mathrm{cm}^{-1}\right)$ & Functional group \\
\hline $3400-3200$ & OH carbohydrate \\
\hline 3250 & $\mathrm{NH}_{2}$ aminoaciddic group \\
\hline 3060 & $\mathrm{CH}$ aromatic group \\
\hline 3015 & $\mathrm{CH}$ alkene group \\
\hline $2950-2850$ & $\mathrm{CH}_{3}$ and $\mathrm{CH}_{2}$ aliphatic group \\
\hline $2500-2000$ & $\mathrm{C} \equiv \mathrm{C}$ or $\mathrm{C} \equiv \mathrm{N}$ \\
\hline 2260 & $\mathrm{C}=\mathrm{C}$ aromatic group \\
\hline 1740 & $\mathrm{C}=\mathrm{O}$ ester fatty acid group \\
\hline 1717 & Humic acid \\
\hline $1700-1715$ & $\mathrm{C}=\mathrm{O}$ fatty acid group \\
\hline $1650-1550$ and $1440-1350$ & -COO- fatty acid salt group \\
\hline $1620-1450$ & Aromatic $\mathrm{C}=\mathrm{C}$ double bonds that are conjugated with $\mathrm{C}=\mathrm{O}$ of $\mathrm{COO}-$ \\
\hline 1650 & $\mathrm{C}=\mathrm{O}$ Amide $\mathrm{I}$ band \\
\hline 1540 & $\mathrm{C}-\mathrm{N}$ Amide II band \\
\hline $1460-1440$ & Carboxylic acid inplane C-O-H bending Aliphatic C-H deformation \\
\hline $1420-1390$ & $\begin{array}{l}\mathrm{OH} \text { vibration of carboxylic group; } \\
\mathrm{C}-\mathrm{H} \text { deformation abutted upon } \mathrm{C}=\mathrm{O}\end{array}$ \\
\hline $1300-1000$ & $\mathrm{C}-\mathrm{O}-\mathrm{C}$ esters \\
\hline $1240-1150$ & $\mathrm{C}-\mathrm{O}$ in carboxylic acid, alcohols, esters and ethers \\
\hline $1160-1120$ & $\mathrm{C}-\mathrm{O}-\mathrm{C}$ polysaccharide \\
\hline $1120-1000$ & $\mathrm{C}-\mathrm{O}$ carbohydrate \\
\hline $850-650$ & $\mathrm{CH}$ or $\mathrm{C}-\mathrm{X}(\mathrm{X}=\mathrm{F}, \mathrm{Cl}, \mathrm{Br}$ and $\mathrm{I})$ out of plane aromatic band \\
\hline 650 & $-\mathrm{OH}$ \\
\hline
\end{tabular}

